\author{
木田豊 ${ }^{1}$ \\ 1 久留米大学医学部感染医学講座基礎感染医学部門 \\ 干 830-0011 福岡県久留米市旭町 67
}

\begin{abstract}
緑膿菌によって産生される主な病原性因子には, 宿主組織を傷害するアルカリプロテアーゼやエラスターゼなど の分泌型プロテアーゼが挙げられる。また, 緑膿菌のゲノム解析は, 病原性因子候補である幾つかの機能未知プロ テアーゼの存在を示唆している。本研究では, 緑膿菌由来の未知のプロテアーゼが, プロテアーゼ活性化受容体 （PARs）を介して宿主免疫応答を修飾する可能性に着目し, 緑膿菌の培養上清から精製された新規のプロテアーゼ LepA によるPARs を介した炎症応答の誘導能について検討した。LepA は, V 型分泌装置 (type V secretion system; T5SS）の two-partner secretion（TPS）による分泌蛋白質に特徵的な TPS モチーフを有し, PAR-1, -2, -4 を介し て NF-кB を活性化することを見出した。一方，生体内における細菌由来プロテアーゼは，組織傷害による菌の拡 散を促すだけでなく，栄養源を獲得するために宿主由来の蛋白質やペプチドの分解に関与すると考えられる。そこ で, 生体内での LepA の役割を解析するために, 急性全身感染マウスモデルを用いて緑膿菌野生型株と lepA 破壊 株の毒力と増殖能を比較した。LepA は，生体内での緑膿菌の毒力と増殖に寄与することが明らかになった。
\end{abstract}

はじめに

緑膿菌は自然界に広く分布し，健常者には本来病原性の 弱い細菌である。しかし, 生体の防御機能が低下した易感 染性の宿主に対して呼吸器感染症, 尿路感染症, 重傷熱傷 感染, 創傷感染, 敗血症など難治性感染症を惹起し，院内 感染の原因菌としても注視されている。緑膿菌により産生 される主要な病原性因子は, 宿主組織を傷害するプロテ アーゼである。なかでもアルカリプロテアーゼ (AprA) (18), エラスターゼ A (LasA) (38), エラスターゼ B (LasB) (44), プロテアーゼ IV (PrpL)（33）は, 詳細に解析されてい る。しかし, 緑膿菌のゲノム解析からは, それら以外にも 病原性因子候補である幾つかの機能未知プロテアーゼの存 在が示唆されている (43)。そこで, 本研究では, 緑膿菌培 養上清から未知のプロテアーゼの精製を試み，V 型分泌装 置 (type V secretion system; T5SS) の two-partner secretion （TPS）による分泌蛋白質に特徵的なTPS モチーフを有 する large extracellular protease (LepA) を同定した。本 稿では，プロテアーゼ活性化受容体（protease-activated receptors; PARs） と緑膿菌の V 型分泌蛋白質について概説 し, 我々の知見である LepA によるプロテアーゼ活性化受 容体を介した炎症応答の誘導 (20) と急性全身感染モデルマ ウスを用いて検討したin vivo に拈ける LepA の役割 (21) に ついて述べる。

\section{1. プロテアーゼ活性化受容体 \\ (protease-activated receptors; PARs)}

PARs は G 蛋白質共役 7 回膜貫通型受容体の一種である (27)。図 1A に示すように, PARs の活性化は通常のリガン ド- 受容体相互作用というよりは，むしろ受容体の $\mathrm{N}$ 末端 側細胞外領域のプロテアーゼ切断により生じた分子内 tethered リガンドが, 受容体の細胞外ループ 2 と相互作用 することにより開始される $(15,27)$ 。現在までに, PARsは 同定された順に PAR-1, -2, -3, -4 と呼ばれる 4 種類が知ら れている。これらの内 PAR-1, $-3,-4$ は, いずれもトロンビン によって活性化される受容体であるが，PAR-1, -4 はトリ プシンによっても活性化される。対照的に, PAR-2 はトロ ンビンでは活性化されず, トリプシン, 肥満細胞トリプター ゼ，血液凝固第 VIIa，Xa 因子等により活性化される受容体 である (34)。酵素的な活性化に加えて, PAR-1, -2, -4 は, 各々の PARサブタイプの tethered リガンド配列となるアミ ド化へキサペプチドによって選択的に活性化される（図 1B）。これらのペプチドは蛋白質分解による活性化とは独 立してPARs を活性化できる。PARs は循環器系, 消化器 系, 呼吸器系, 中枢神経系を含む様々な組織や細胞に発現 し (15, 27, 34), PARs の活性化は, 発生, 細胞増殖, 免 疫, 炎症など多様な生理学的・病態生理学的な役割を担っ ている $(39,40)$ 。 
A

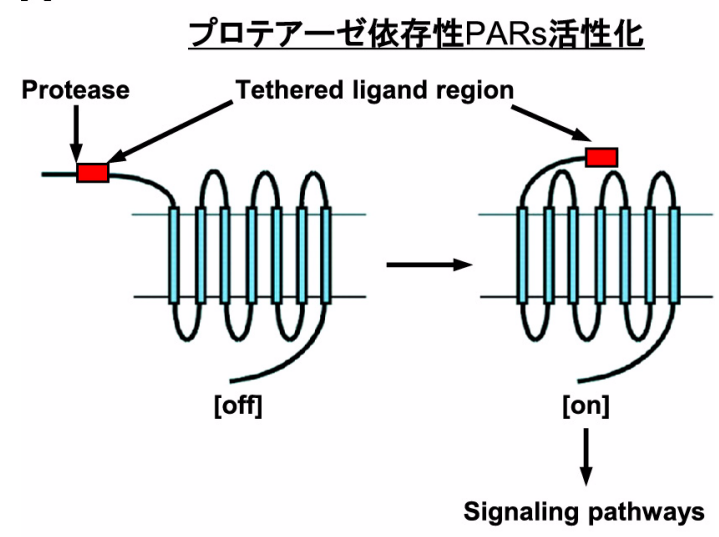

B

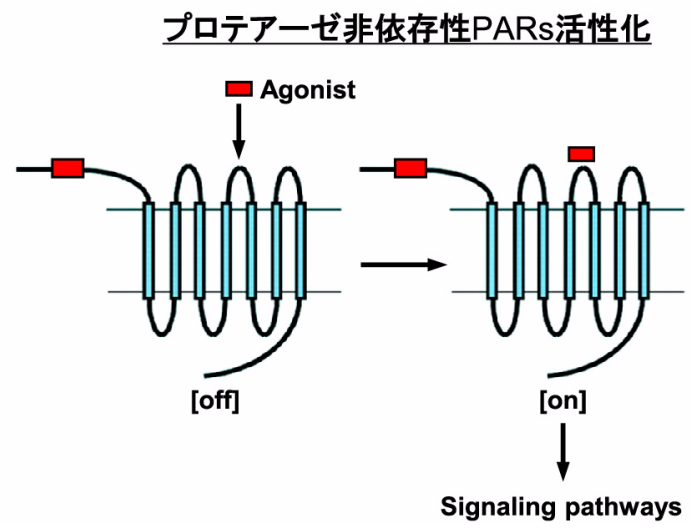

図 1. プロテアーゼ活性化受容体の活性化機構 A. プロテアーゼ依存性 PARs 活性化，B．プロテアーゼ非依存性 PARs 活性化。

前述のような活性化機構で PARs が活性化されると, G 蛋白質が共役したシグナル伝達機構が働く［phospholipase C (PLC) の活性化, inositol 1,4,5-triphosphate $\left(\mathrm{InsP}_{3}\right)$ と diacylglycerol (DAG)の生成, 細胞内 $\mathrm{Ca}^{2+}$ 濃度の上昇, protein kinase C (PKC) の活性化] (27, 34)。PLC の活性化は, $\operatorname{InsP}_{3}$ の生成を促して, 細胞内 $\mathrm{Ca}^{2+}$ と $\mathrm{DAG}$ を増加させる。細胞 内 $\mathrm{Ca}^{2+}$ の増加は calmodulin-dependent kinase を活性化し, DAG の増加はPKCを活性化する。活性化したPKCは, mitogen-activated kinase カスケード (extracellular signalregulated kinase 1/2 経路, c-Jun N-terminal kinase 経路, p38 kinase 経路)を活性化させることで, 転写因子AP-1や $\mathrm{C} / \mathrm{EBP} \beta$ 等の活性化を誘導する。一方では，PKC が転写因 子 NF-кB 等の活性化を誘導する(17)。これらの活性化され た転写因子群が様々な遺伝子の転写に関与し, 生体の多彩 な応答を生じさせる。

PARs はトロンビンやトリプシンのような塩基性アミノ 酸のカルボキシル末端側を切断する基質特異性のプロテ アーゼにより活性化される。従って，そのような基質特異 性を示す細菌由来プロテアーゼは, PARs を活性化すると 考えられる。なかでも細菌感染に打ける PAR-2 活性化の 役割は詳細に解析されている。例えば, Porphyromonas gingivalis 由来のプロテアーゼであるジンジパインは, PAR2 を活性化し宿主の炎症や免疫応答調節を修飾する $(6,24)$ 。
また，PAR-2 欠失マウスを用いた Citrobacter rodentium 感染 大腸炎モデルに扣いて，病態の特徴である腸管壁傷害や腸 管壁への顆粒球浸潤は減弱することが報告された (12)。加 えて, 同マウスでのP.gingivalis 感染歯周病モデルにおいて は，病態の特徵である歯槽骨の吸収や歯肉溝への炎症性細 胞浸潤が減弱する (16)。一方, Serratia marcescens 由来のプ ロテアーゼであるセラリシンは，感染宿主の組織破壊や体 内への病原体の侵襲に中心的な役割を担ら病原性因子の一 つである (28)。そこで，著者らはセラリシンによる PAR-2 を介した炎症応答の活性化について検討した。セラリシン は，ヒト肺上皮細胞株において IL-6 及び -8 の mRNA 発現 を誘導し，PAR-2 を介して炎症応答に重要な転写因子群で ある AP-1, C/EBP $\beta, N F-\kappa B$ を活性化すること報告した (19)。 これらの研究の他にも, 細菌感染に伴ら炎症や免疫応答制 御における PAR-2 の重要性が示唆されている $(37,41,42) 。$ 細菌感染における PAR-2 以外の PARs の役割に関しての理 解は十分ではないが, Helicobacter pylori 感染胃炎モデルマ ウスを用いた研究では，PAR-1の活性化が抗炎症応答を誘 導し，胃炎の重症度を低下させることが報告されている （45）。このように，細菌感染に打ける PARs の活性化は，生 体に対して炎症応答の増強と減弱の両方を誘導すると考光 られる。

\section{2. 緑膿菌の V 型分泌蛋白質}

グラム陰性菌から分必される蛋白質は, 内膜から順に, ペリプラスム，ペプチドグリカン，そして，外膜を通過し て輸送される。グラム陰性菌には, I 型分泌装置 (type I secretion system; T1SS）から VI 型分泌装置（type VI secretion system; T6SS) と呼ばれる6種類の分泌装置が存在 する (8)。緑膿菌では IV 型分泌装置を除いた他のすべての 分泌装置が備わる (3，9)。なかでも V 型分泌装置（T5SS） は，autotransporter (AT) secretion（図 2A）と two-partner secretion（TPS）（図 2B）の二種類の経路から構成されてい る $(2 ， 14)$ 。この T5SS による蛋白質の分泌は，1）輸送さ れる蛋白質が，自身のシグナルペプチド依存的に Sec 移送 装置を介して内膜を通過，2）内膜を通過した蛋白質が，外 膜に形成された $\beta$-バレル型のチャネルを通じて菌体外に輸 送，という二段階の過程から成る $(23 ， 29)$ 。最終的に，菌 体外に輸送された蛋白質は，外膜の表面に結合した状態で 存在するか, 自己消化や何らかのプロテアーゼにより切断 後，菌体外に放出される。あるいは，これら両方である場 合も知られている。他の分泌装置と異なる特徵は，外膜輸 送に利用される $\beta$-バレル型のチャネルである。これらが, 輸送される蛋白質自身で形成される場合を AT 分泌系, 別 個の蛋白質によって形成される場合をTPS 系と呼ぶ。AT 蛋白質は，分泌されるパッセンジャードメインの C 末端側 に，それ自身のトランスポータードメインが連結されてい る。一方, TPS 系では, 分泌される蛋白質である TpsA と, その特異的なトランスポーターである TpsB の二種類の蛋 白質から構成される。T5SS トランスポータードメイン 
A

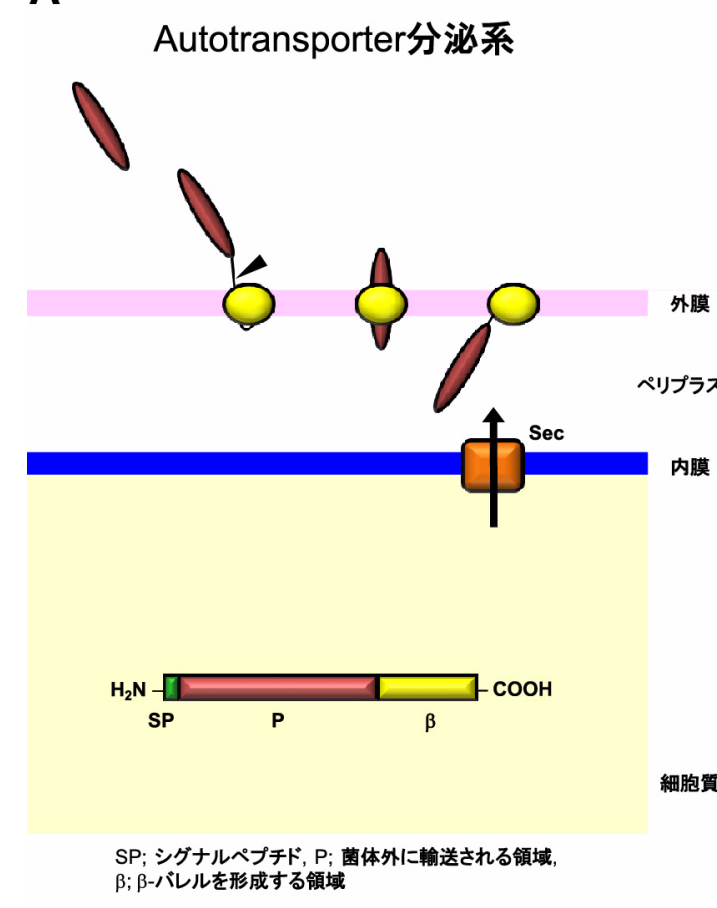

B

\section{Two-partner分泌系}
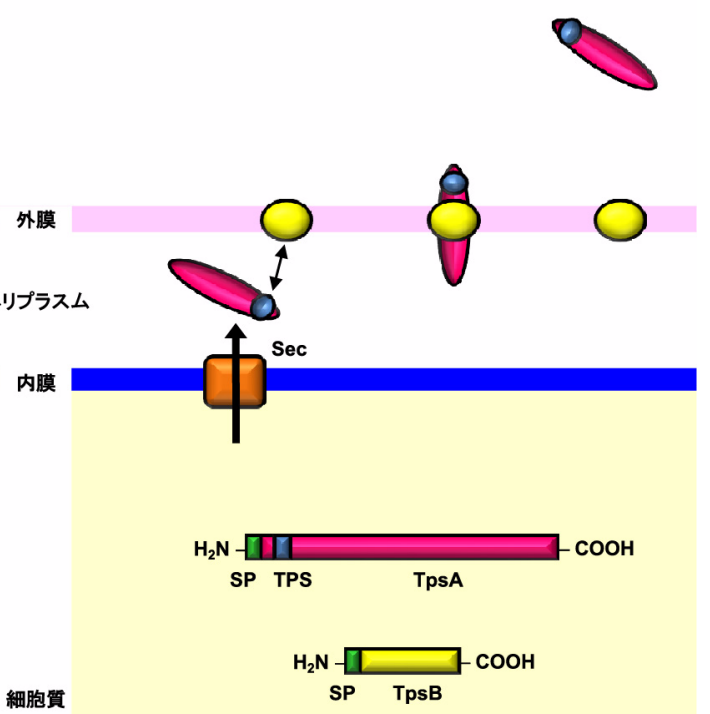
SP; シグナルペプチド, TPS; TpsB蛋白質と相互作用する領域,
TpsA; 菌体外に輸送される蛋白省, TpsB; $\beta$-バレルを形成する 蛋白質

図 2. V 型分泌装置

A. Autotransporter 分泌系，B. Two-partner 分泌系。

は，異属間で高度に保存されているが，パッセンジャード メインは非常に多様である。性状が明らかにされたパッセ ンジャードメインの機能の多くは, 酵素活性（プロテアー ゼ，ペプチダーゼ，リパーゼ，エステラーゼ), 宿主侵入 能，接着性，細胞毒性なぞであり，グラム陰性菌の病原性 に関与する $(14)$ 。

緑膿菌 PAO1 株のゲノム配列からは, 3 つの AT 蛋白質の 存在が示唆されている (43)。最もよく研究されている AT 蛋白質 PA5112（EstA）は，ラムノリピッド産生に関わる エステラーゼであり, estA 破壊株では運動性の欠失やバイ オフィルム形成の減弱が認められる (46)。他の 2 つの AT 蛋白質は, PA0328 (AaaA) と PA3535 (EprS) である。AaAA は，アルギニン特異的アミノペプチダーゼであり，緑膿菌 の感染成立に重要な因子であることが報告されている (25)。近年, 著者らは, EprSがトリプシンに類似した活性 を示すセリンプロテアーゼであり, PARsを介して炎症応 答を誘導することを報告した $(22)$ 。一方，緑膿菌の TPS 系 には, 6 つの TpsA-TpsB 蛋白質 Tps1: PA0041-PA0040, Tps2: PA0690-PA0692, Tps3: PA2462-PA2463, Tps4: PA2542PA2543, Tps5: PA4541 (LepA)-PA4540 (LepB), Tps6: PA4625 (CdrA)-PA4624 (CdrB) の存在が示唆されている。これらの TpsA 蛋白質は, 何れも細胞表面蛋白質のインテグリンとの 接着に重要な RGD 細胞接着モチーフを数個ずつ有するた め，細胞接着能を示すことが推測される(26)。しかし，こ れらの TpsA蛋白質に存在する RGD モチーフの意義につい ては現在のところ解明されていない。また，特性が解析さ れた緑膿菌TPS系蛋白質はTps5 と Tps6である。Tps5 (LepA-
LepB）については後述するが，Tps6（CdrA-CdrB）に関し て，CdrA は cyclic-di-GMP により発現を調節される接着因 子であり, 緑膿菌のバイオフィルム産生と菌の自己凝集を 促進することが報告された (4)。このように, 緑膿菌の V 型 分泌蛋白質は, 緑膿菌の病原性に関与することが明らかに されつつある。

\section{3. 緑膿菌 LepA による PARs の活性化}

緑膿菌が産生する様々なプロテアーゼの中でも，AprA， LasA，LasB，PrpLは，緑膿菌感染による病態形成に重要 な役割を果たすことが知られている。著者らはAprA と同 じ性質を示すセラリシンが PAR-2を活性化することを報告 した（19）。一方，他のグループからは，LasB は PAR-2 を 不活性化することが報告された (7)。そこで, 緑膿菌由来の 未知のプロテアーゼが，PARsを活性化または不活性化す ることで，サイトカイン産生のような宿主免疫応答を修飾 する可能性に着目し, 緑膿菌培養上清から未知のプロテ アーゼの精製を試み，その PARs 活性化能を評価すること にした。

1）緑膿菌臨床分離株培養上清のカゼインザイモ グラフィー

緑膿菌臨床分離株が，未知のプロテアーゼを産生するか を検討するために，それらの培養上清をカゼインザイモグ ラフィーにて解析した。緑膿菌の既知のプロテアーゼであ る AprA, LasA, LasB, PrpL は, カゼインあるいはゼラチ ンザイモグラフィーに拈いて，それぞれ50，160，160，200$\mathrm{kDa}$ のバンドを示すことが知られている(5)。図 3 のレーン 1 


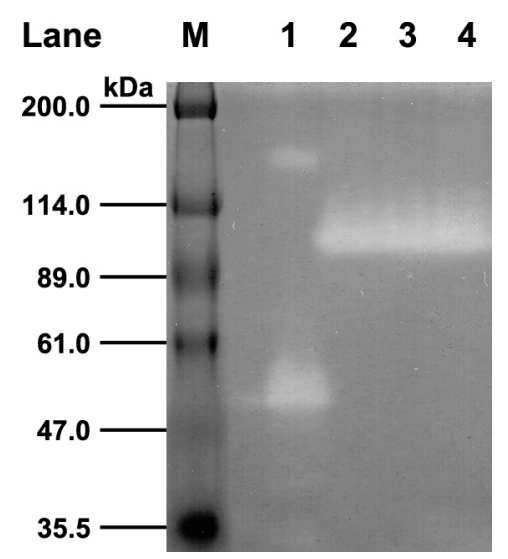

図 3. 緑膿菌臨床分離株培養上清のカゼインザイモグラフィー レーン $\mathrm{M}$, 分子量マーカー ; レーン $1, \mathrm{PAO} 1$; レーン 2, KU2 ; レーン 3, $\alpha$ 05-6; レーン 4, $\alpha$ 05-43 (Kida et al., (2008) Cell. Microbiol. 10, 1491-1504. John Wiley \& Sons, Inc より転載許諾)。

に示すよらに, AprA と LasB を産生する緑膿菌標準株の PAO1 では 50,160-kDa のバンドが認められたが, 緑膿菌臨 床分離株 KU2, $\alpha$ 05-6, $\alpha$ 05-43 では AprA, LasA, LasB, PrpL とは異なる 100-kDa のバンドが認められた（図 3 のレーン 2-4)。従って, これらの結果は, 緑膿菌が AprA, LasA, LasB, PrpL とは異なる未知のプロテアーゼを産生しうるこ とを示唆している。

\section{2）LepAの精製と同定}

カゼインザイモグラフィーで100-kDa を示したプロテ アーゼを陰イオン交換クロマトグラフィー, アフィニティ クロマトグラフィーにより精製した。精製蛋白質は, SDSPAGE にて100-kDaを示した。精製蛋白質のN末端アミノ酸 配列を解析し, データベース検索を行った結果, 緑膿菌 PAO1 の PA4541 (1,417 アミノ酸) と相同であった。この蛋 白質を LepA (large extracellular protease from P. aeruginosa), それをコードする遺伝子をlepA と名付けた。lepA が 100$\mathrm{kDa}$ プロテアーゼをコードすることを確認するために, lepA 破壞株を作製し, 緑膿菌野生型 $\mathrm{KU} 2$ とそのlepA 破壞株 （KU2NlepA）に打壮プロテアーゼ産生能をカゼインザイ モグラフィーにより比較した。その結果, 野生型 KU2 では 100-kDa のバンドが認められたが, KU2AlepAではそれは確 認されなかった。従って, これらの結果は, lepA が緑膿菌の 新規な分泌プロテアーゼをコードすることを示していた。

次に, 各種のデータベースを用いて LepAのアミノ酸配 列を解析した。SignalP3.0 解析は，1-53 アミノ酸がシグナ ルペプチドであることを予測した。また，PROSITE 解析 は, LepA がトリプシン様セリンプロテアーゼ活性中心モ チーフ(171-182アミノ酸) と RGD 細胞接着モチーフ (680682 アミノ酸)を有することを示した。加光て, LepA は TPS 系に上って分泌される蛋白質に多く見られる赤血球凝集活 性ドメイン（53-166アミノ酸）を有していた。さらに, TPS による分泌蛋白質に特徽的な TPS モチーフ（137-141 アミ ノ酸）が認められた。TPS 系は細胞外に分泌される蛋白質 と, その分泌に関与寸る蛋白質から構成され, それらをコー
ドする遺伝子は一つのオペロンを構成するか，近隣の遺伝 子座に存在することが知られている。実際に, LepA をコー ドする遺伝子 (lepA) は, LepAの分泌関わると推測され る蛋白質（PA4540）をコードする遺伝子とオペロンを構成 していた。また，各種データべースを用いて PA4540のア ミノ酸配列を解析すると，PA4540は59-134 アミノ酸に蛋 白質輸送ドメイン（POTRA_2; pfam08479）を有していた。 POTRA_2ドメインは, グラム陰性菌の外膜において蛋白質 輸送に関わるポリン様の蛋白質によく認められる。さらに, PSIPRED 解析は, PA4540 がポリン形成を示唆する 18-22の 防ハルを含むことを示した。従って，これらの結果は， PA4540 が TpsB 蛋白質であり, PA4541 とオペロンを形成し ていることを示唆し，著者らはPA4540をLepB，それを コードする遺伝子をlepB と名付けた。

\section{3）LepA による PARs の活性化と炎症応答の誘導}

PAR-1, -2, -4 の活性化は, 炎症, 免疫応答の修飾飞中心的 な役割を果たすと考光ら机ている(37，41，42)。対照的に， PAR-3 は単独でシグナルを伝えず, PAR-1, -4 のアクセサ リー分子として機能することが報告されている $(30 ， 32)$ 。 そこで，LepA による PAR-1, -2, -4を介した NF-kB の活性 化を調べるために，機能的な PARs を発現しないアフリカ ミドリザル腎臓繊維芽様細胞株 COS-7へヒト PARs 発現べ クターと NF-kBレポーターベクターをトランスフェクショ ンして実験に使用した。図 4A に示すように, LepA 刺激に 対する NF-kBレポーターの活性化は, ヒト PAR-1, -2, -4 の トランスフェクション量依存的に認められたが, コント ロールでは認められなかった。また，図 4B に示すように, LepA による NF- $\mathrm{KB}$ の活性化は PAR-1, -4を活性化するト口 ンビン（図 4C）と PAR-1, -2, -4 を活性化するトリプシン （図 4D）と同様に用量依存的に認められた。また, プロテ アーゼによるPARs の活性化は, PARs の $\mathrm{N}$ 末端側細胞外 領域がプロテアーゼにより切断されて, tethered リガンド 領域が露出することを必要とする。そこで, LepA が PARs 活性化プロテアーゼであるトリプシンやトロンビンと同様 の形式で, PARs の N 末端側細胞外領域の合成ペプチドを 切断するのかについて検討した。逆相 HPLC と質量スペク トルによる解析の結果, LepA が PAR-1, -4 を活性化するト ロンビンと PAR-1, - 2 , -4を活性化するトリプシンと同様に, tethered リガンド領域を露出させる形式で, PARs の N 末端 側細胞外領域の合成ペプチドを切断することが示された。

著者らは，S. marcescens のセラリシンがヒト細気管支上 皮細胞株 EBC-1 に沶いて PAR-2 を介して, 炎症応答を誘 導することを以前に報告していた（19）。そこで，LepA が EBC-1細胞に打いて IL-8産生を誘導するのかをELISAによ り調べた。図 5A に示すように, LepA はトロンビンやトリ プシンと同様に IL-8 産生を誘導した。また，ヒト PAR-2 の アンタゴニストペプチド（FSLLRY-NH $\mathrm{N}_{2}$, LSIGRL-NH $\mathrm{N}_{2}$ ) は その誘導を抑制した（図 5B)。以上の結果から, 緑膿菌 LepAはヒト PAR-1, -2,-4を介してNF-kBを活性化し, IL-8産 生などの炎症応答を誘導することが明らかとなった (20)。 
A

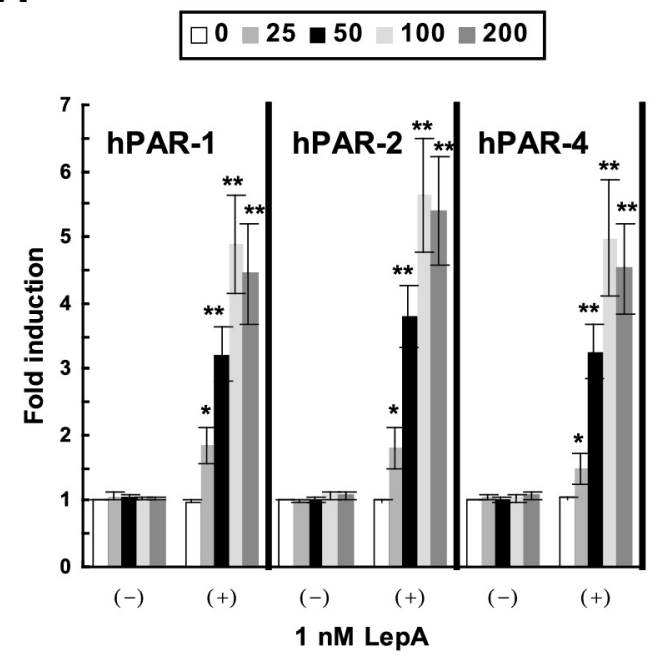

C

$\square$ Mock $\square$ hPAR-1 $\square$ hPAR-2 $\approx$ hPAR-4

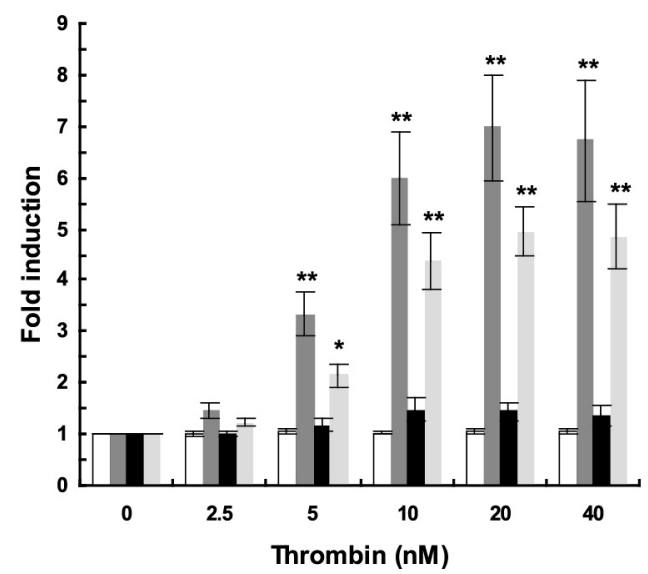

B

$\square$ Mock $\square$ hPAR-1 $\square$ hPAR-2 $\square$ hPAR-4

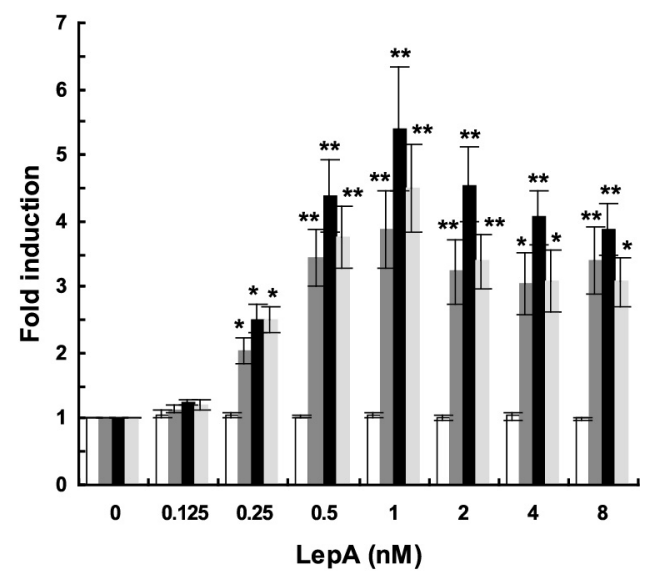

D

$\square$ Mock $\square$ hPAR-1 $\square$ hPAR-2 $\square$ hPAR-4

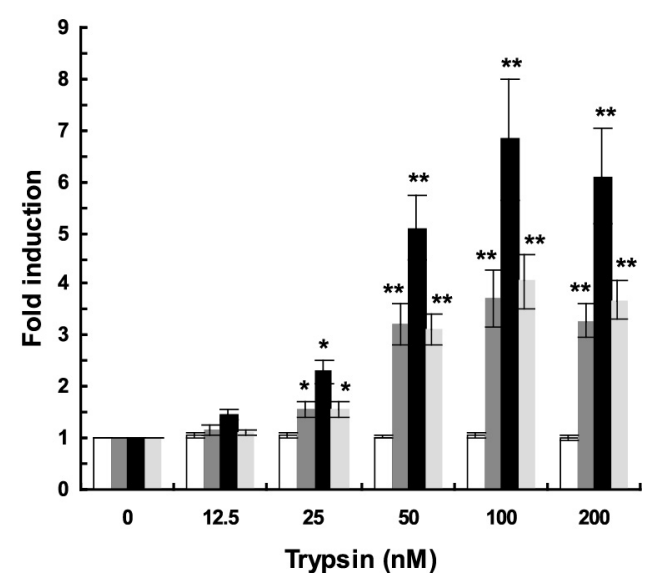

図 4. ヒト PARs をトランスフェクションした COS-7 細胞における LepA 刺激による NF-kB 依存性プロモーターの活性化

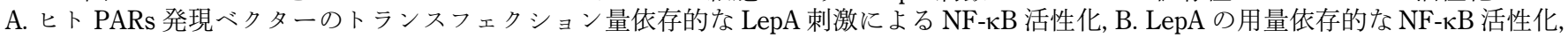

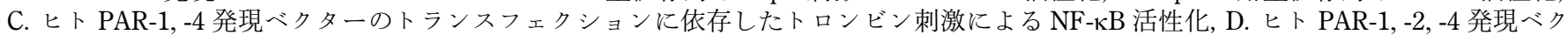

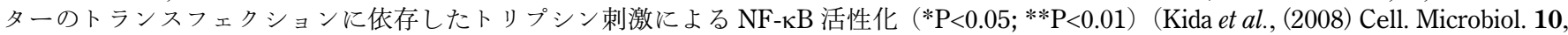
1491-1504. John Wiley \& Sons, Inc より転載許諾)。

\section{4. 生体内における LepA の役割}

前述のように，著者らは，LepAによるPARsを介した炎 症応答誘起能を明らかにしたが，生体内に抢ける LepA の 役割に関しての解析は不十分であった。生体内に拈ける細 菌由来プロテアーゼは, 組織傷害による菌の拡散を促すだ けでなく，栄養源を獲得するために宿主由来の蛋白質やぺ プチドの分解に関与すると考兄られる。例光ば, 緑膿菌の AprAやLasB, また, 腸管凝集付着性大腸菌のPic プロテアー ゼは, ムチンを分解することで, 菌の栄養源獲得機構の一 つとして機能する $(1,13) 。 一$ 方, 緑膿菌のへモリジンの一 つである溶血性ホスホリパーゼ C $(\mathrm{PlcH})$ は, 病原性に関 与寸ることが明らかにされているが (35)，へモリジンの役 割として重要な鉄の獲得に関与するかは解明されていな い。ヒトに打ける鉄の大部分は, 赤血球内にへモグロビン なぞの鉄結合蛋白質として存在する。また，細胞外の少量
の鉄は，血清中に存在するトランスフェリンや粘膜表面に 存在するラクトフェリンのよらなキャリア一蛋白質に抱合 されている $(31 ， 36)$ 。従って，へモリジンによる赤血球か らの鉄結合性蛋白質の放出とプロテアーゼによるそれらの 分解は, 細菌による鉄の利用に重要と考光られる。そこで, 著者らは LepA と PlcH の協調作用が限定的な栄養源存在下 に扮ける緑膿菌の増殖に関与し, 生体内での緑膿菌の毒力 と増殖に寄与するのかについて検討した。

1）最少培地での緑膿菌の増殖における LepA の役割

先ず，LepA が緑膿菌の増殖に関与するのかを検討する ために，唯一の炭素及び窒素源としてアルブミンまたはへ モグロビンのみを含む最少培地に沶けるlepA破壊株の増殖 を調べた。その結果, ぞちらの培地に扒いてもlepA破壊株 の増殖率は野生型 KU2 株よりも低下して扣り, 緑膿菌の増 殖に LepA の働きが重要なことが示唆された。次に、へモ グロビン培地にキレート剤を添加して細菌の増殖に重要な 
A

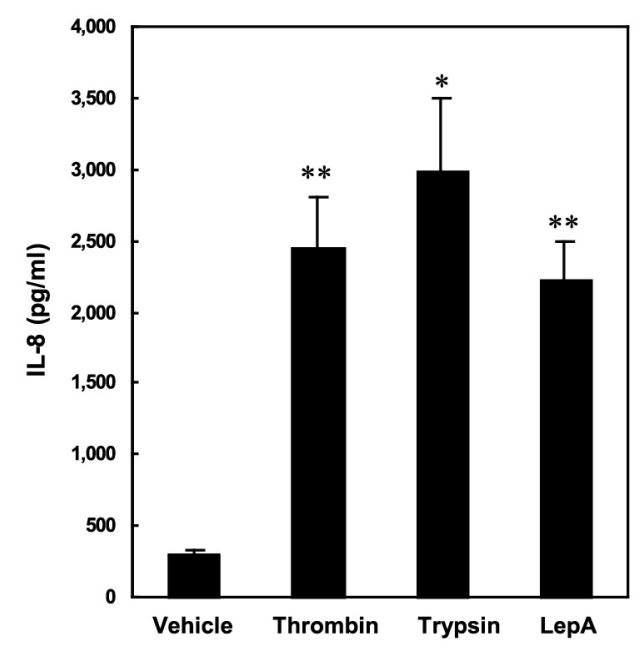

B

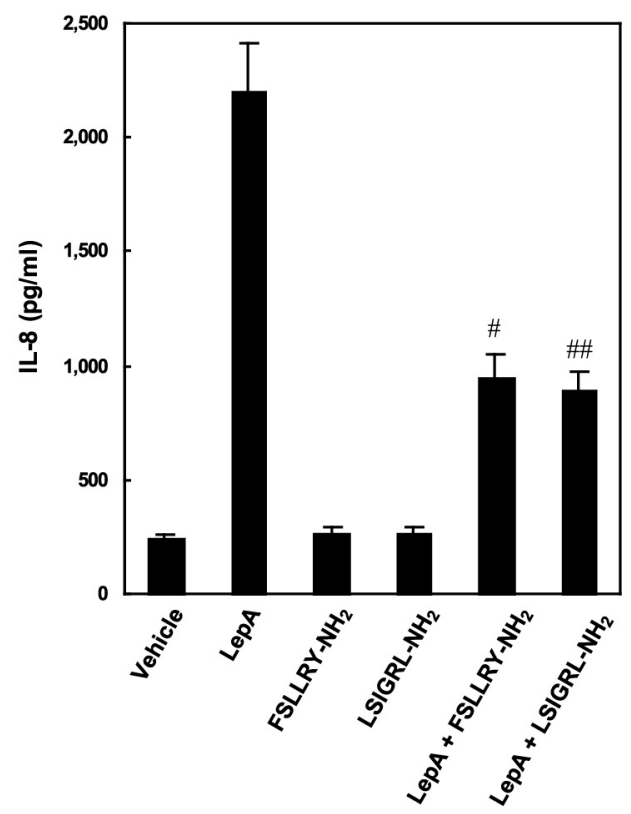

図 5. ヒト細気管支上皮細胞株 EBC-1 飞抢ける LepA 刺激による IL-8 産生の誘導

A. LepA はトロンビンやトリプシンと同様に IL-8 産生を誘導 (*P $<0.05 ; * * \mathrm{P}<0.01), \mathrm{B}$. ヒト PAR-2 アンタゴニストペプチドは LepA 刺激 による IL-8 産生を抑制（\#P<0.05; \#\#P<0.01）（Kida et al., (2008) Cell. Microbiol. 10, 1491-1504. John Wiley \& Sons, Inc より転載許諾）。

A

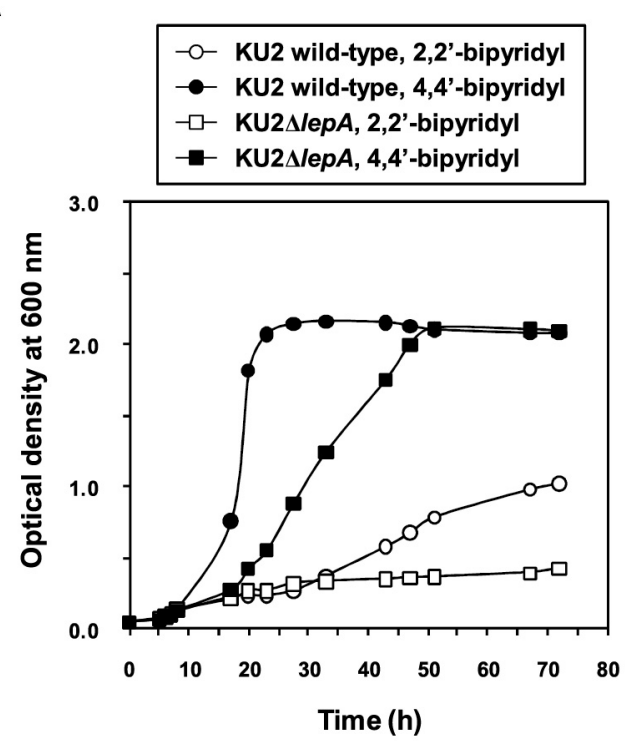

B

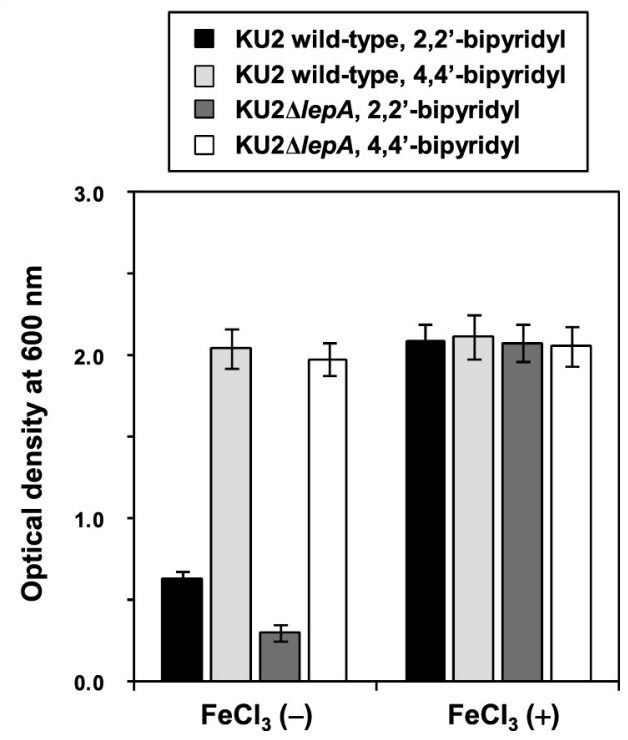

図 6. 鉄制限条件下でのへモグロビン培地飞打ける緑膿菌野生型 KU2 株とそのlepA 破壊株の增殖 A. 増殖に対する 2,2'-ビピリジルによる鉄制限の効果，B．過剩量の鉄添加による增殖の回復（Kida et al., (2011) Infect. Immun. 79, 211219. American Society for Microbiology より転載許諾)。

鉄の利用を制限した時のlepA 破壊株の増殖を調べた。図 $6 \mathrm{~A}$ に示すように, 鉄キレート能のある 2,2 - ビピリジル存在下 に打沙野生型 KU2 株の増殖率は, 鉄キレート能のない 4,4'-ビピリジル存在下よりも低下した。一方，2,2'-ビピリ ジル存在下に打けるlepA 破壊株の増殖は, 野生型 KU2 株 よりもさらに強く抑制された。また，2,2'-ビピリジル添加 培地飞過剩量の鉄を添加して48時間培養した時の各株の 増殖率は，4,4'-ビピリジルを添加した鉄を制限しない条件
下と同程度まで回復した（図 6B）。従って，これらの結果 は，LepA によるへモグロビンの分解が，緑膿菌の増殖に 必要な鉄を獲得する上で重要な役割を果たすことを示唆し ていた。

\section{2）緑膿菌の増殖における赤血球の利用}

へモリジンは，赤血球を溶解し，へム鉄やへモグロビン を放出させるので，へモリジンは，細菌の鉄代謝に関与す ると考兄られる。緑膿菌は $\mathrm{PlcH}$ と呼ばれるへモリジンを 


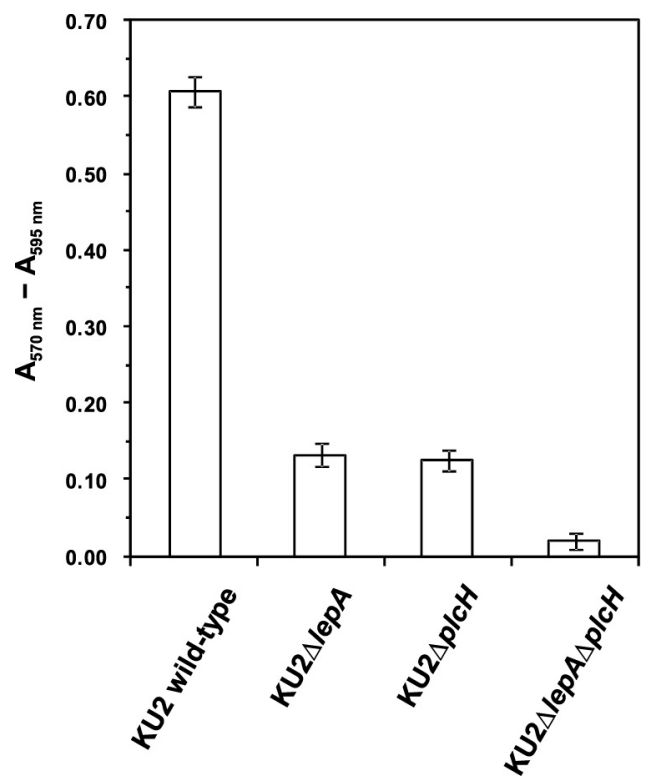

図 7. 唯一の栄養源として赤血球のみを含む最少培地に打ける緑 膿菌野生型 $\mathrm{KU} 2$ 株とその lepA 及び plcH 破壞株の増殖 $\mathrm{KU} 2 \Delta l e p A$ と KU2 $\Delta p l c H$ の増殖の差が有意ではないことを除いて, 他の全ての組合せに打ける増殖の差は $\mathrm{P}<0.01$ で有意 (Kida et al., (2011) Infect. Immun. 79, 211-219. American Society for Microbiology より転載許諾)。

産生するが，緑膿菌による鉄の獲得に関与するかは，明ら かではなかった。そこで，唯一の栄養源として赤血球のみ を含む最少培地を用いて, $\mathrm{PlcH}$ が赤血球からの栄養源獲得 に関与するのかをアラマーブルーアッセイにより検討し た。このアッセイは細菌の増殖に伴う細菌細胞の酸化還元 活性変化を, アラマーブルーの酸化型から還元型への変化 を測定することで評価する方法である。始めに，ヒッジ赤 血球を懸濁した生理食塩水に各菌株を接種し， $37^{\circ} \mathrm{C} て ゙ 24$ 時間培養した。次に, アラマーブルー試薬を添加し， $37^{\circ} \mathrm{C}$ で 8 時間培養した。そして 570 と $595 \mathrm{~nm}$ でのアラマーブ ルーの吸光度を測定し, $570 \mathrm{~nm}$ での還元型アラマーブルー の吸光度から $595 \mathrm{~nm}$ での酸化型アラマーブルーの吸光度 を差し引くことで，緑膿菌の増殖レベルを現した。図７に 示すように, $p l c H$ 破壞株の増殖率は, 野生型 $\mathrm{KU} 2$ 株と比 較すると低下した。また，lepA 破壊株の増殖率も同様に低 下した。特に, 二重破壊株の増殖率には, 野生型 KU2 株と 比較してさらに大きな低下を認めた。予想に反して, lepA 破壊株と同様に $p l c H$ 破壊株は, 唯一の栄養源として赤血球 を利用して增殖することができた。緑膿菌は $\mathrm{PlcH}$ とは異 なるへモリジンとして熱安定性の糖脂質 (ラムノリピッド) を産生することが知られている(10)。従って，plcH破壊株 がラムノリピッドを利用して赤血球からへモグロビンを放 出させることで, LepA によるへモグロビンの分解に繋がっ て plcH 破壞株の增殖が認められたのかもしれない。これら の結果から, LepA と PlcH の協調作用が栄養源としての赤 血球の利用に寄与することが示唆された。

3）緑膿菌の毒力における LepA の役割

細菌の増殖は, 旮の毒力に密接に関連すると考兄られる。

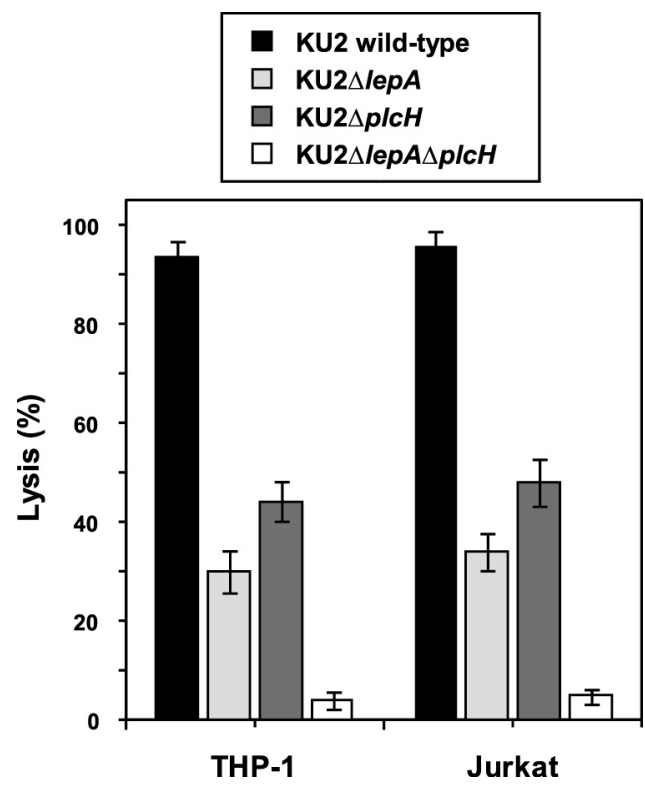

図 8. ヒト細胞株に対する緑膿菌野生型 $\mathrm{KU} 2$ 株とその lepA 及び $p l c H$ 破壊株の細胞毒性

$\mathrm{KU} 2 \Delta l e p A$ と KU2 $\Delta p l c H$ の細胞毒性の差は $\mathrm{P}<0.05$ で有意, 他の全て の組合せに抢ける細胞毒性の差は $\mathrm{P}<0.01$ で有意 (Kida et al., (2011) Infect. Immun. 79, 211-219. American Society for Microbiology より 転載許諾)。

そこで，ヒト細胞株（単球様細胞株 THP-1 及び T 細胞株 Jurkat）に対する緑膿菌の細胞毒性に, lepA あるいは $p l c H$ の 不活性化が影響を及湆すのかを，乳酸脱水素酵素放出アッ セイにより検討した。図 8 亿示寸ように, 野生型 KU2 株で は約 95\%の細胞溶解を認めたが，その值はlepA 破壊株で は約 30\%, plcH 破壊株では約 $45 \%$ までに低下して扔り, $l e p A$ や $p l c H$ の不活性化は細胞毒性の低下に繋がることが示 された。緑膿菌は，プロテアーゼやへモリジンに加えてエ キソトキシンやエキソエンザイムなどの様々な病原性因子 を産生することが知ら机ている (11)。従って，plcH 破壊株 と比較した lep $A$ 破壊株の細胞毒性の低下は, lepA 破壊株で の様々な病原性因子の産生低下によると考兄られる。特に, 二重破壊株の細胞毒性は,さらに低下していたことから(約 5\%), LepA と PlcHの協調的な働きが緑膿菌の細胞毒性に寄 与寸るものと推測された。また，シクロフォスファミド投 与マウスを用いた緑膿菌急性全身感染モデルにより，生体 内での緑膿菌の毒力に扔ける LepA と PlcH の役割を検討し た（図 9）。そ玌热の菌株を腹腔内に感染させて，マウス の生存を観察した。その結果, 各菌株の毒力の強さは, 野生型 $\mathrm{KU} 2$ 株 $\left(6.70 \times 10^{3} \mathrm{CFU} /\right.$ mouse $\left.\mathrm{LD}_{50}\right)>p l c H$ 破壊株 $\left(1.06 \times 10^{5} \mathrm{CFU} /\right.$ mouse $\left.\mathrm{LD}_{50}\right)>$ lepA 破壊株 $\left(2.46 \times 10^{6} \mathrm{CFU} /\right.$ mouse $\left.\mathrm{LD}_{50}\right)>$ 二重破壊株 $\left(5.37 \times 10^{7} \mathrm{CFU} /\right.$ mouse $\left.\mathrm{LD}_{50}\right)$ の 順であった。これらの結果は, in vitro の細胞毒性の結果と よく一致していた。このように, LepA と PlcH は生体内で の緑膿菌の毒力に重要な役割を果たすことが示された。さ らに, 生体内での緑膿菌の増殖に打ける LepA と $\mathrm{PlcH}$ の役 割について検討した。シクロフォスファミド投与マウスの 腹腔内に緑膿菌を感染させて，4 時間後に全血と腹腔洗浄 
A

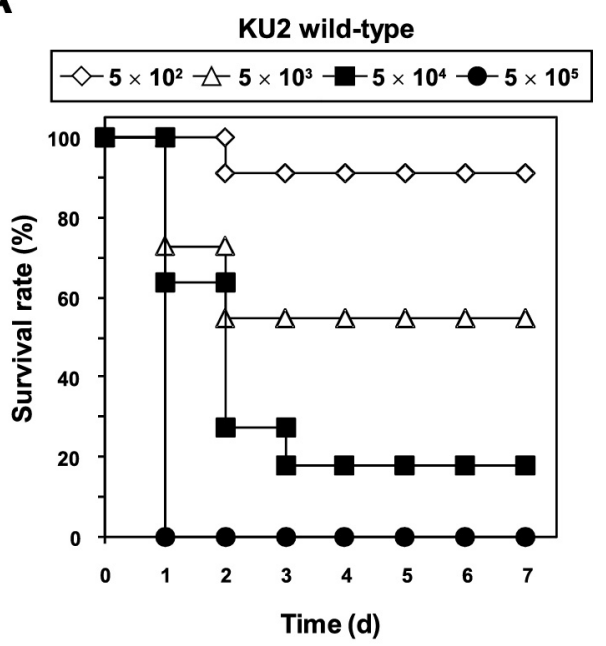

C

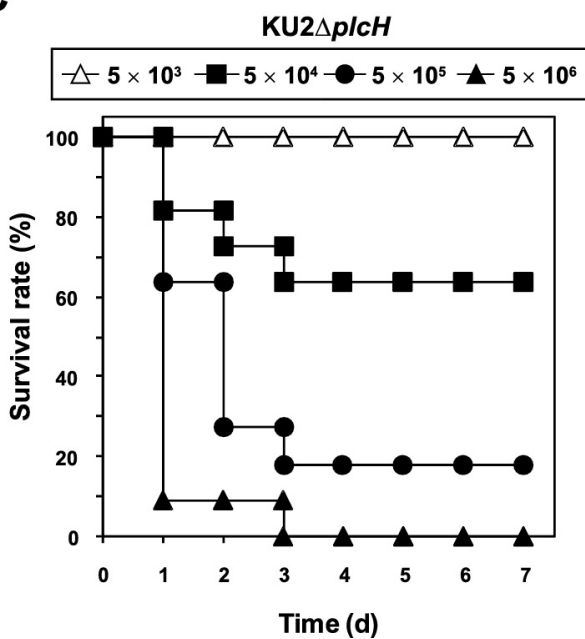

B

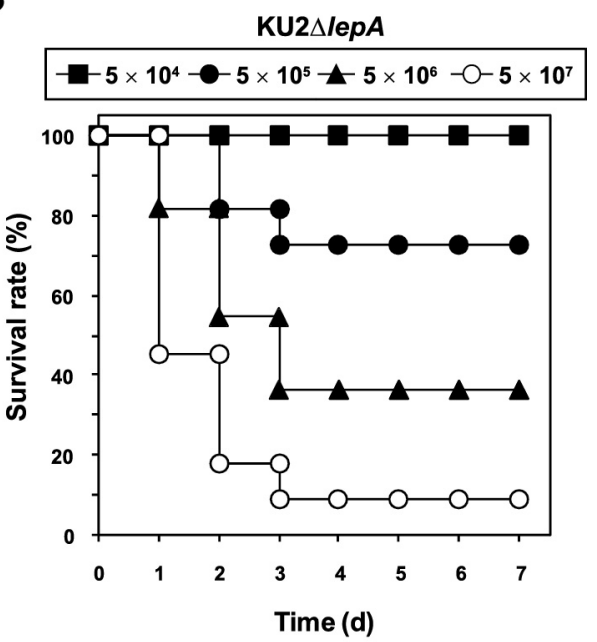

D

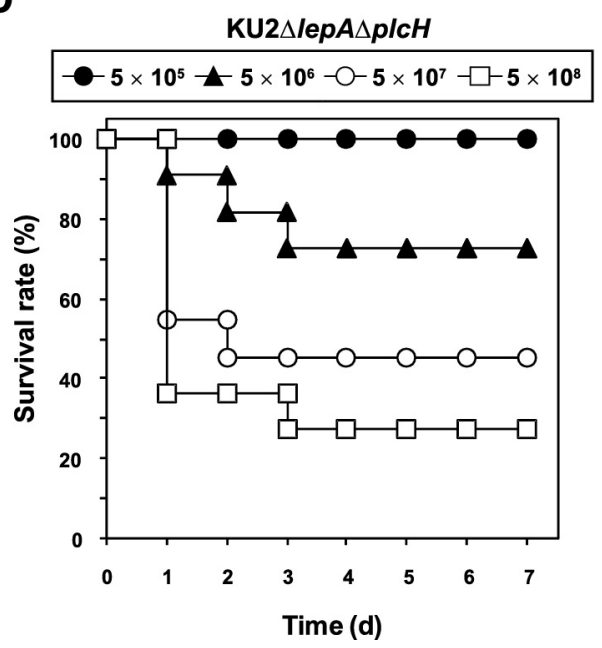

図 9. 緑膿菌野生型 $\mathrm{KU} 2$ 株とその lepA 及び plcH 破壊株を腹腔内感染させた白血球減少 $\mathrm{ddY}$ マウスの生存率 A. 緑膿菌野生型 $\mathrm{KU} 2$ 株の感染，B.lepA 破壊株の感染，C. plcH 破壊株の感染，D. lepA 及び plcH二重破壊株の感染（Kida et al., (2011) Infect. Immun. 79, 211-219. American Society for Microbiology より転載許諾)。

A

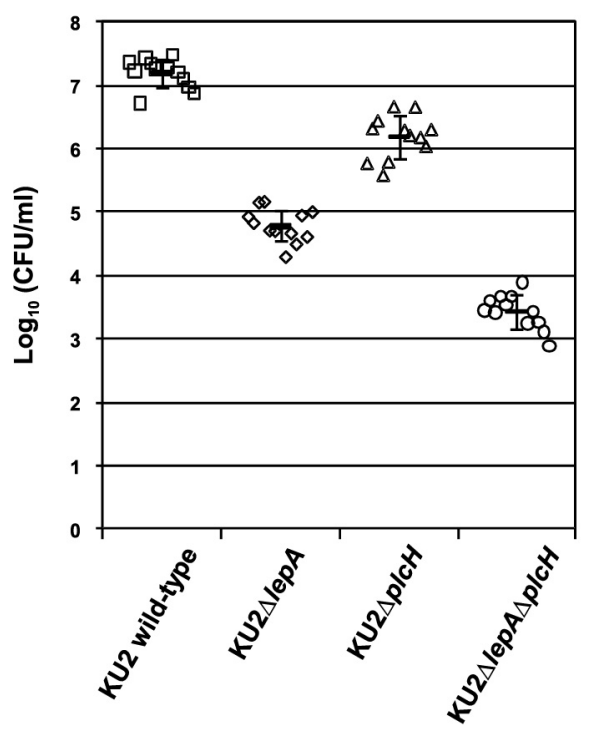

B

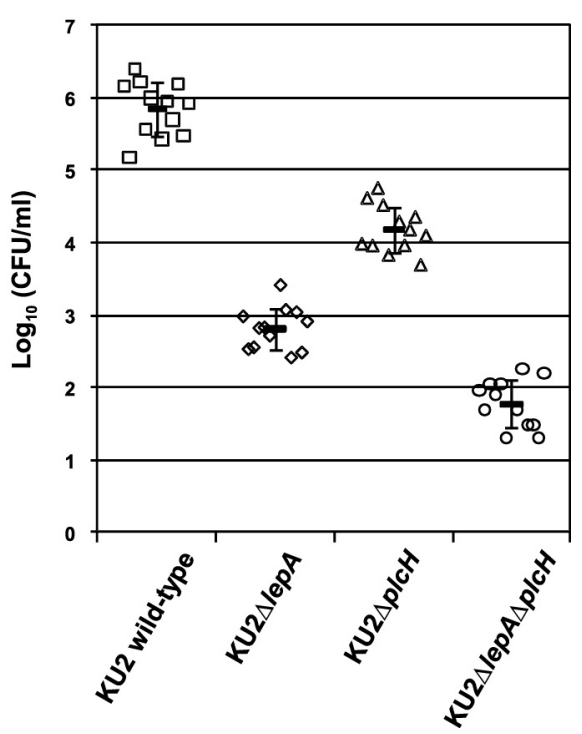

図 10. 白血球減少 ddY マウスに打ける緑膿菌野生型 KU2 株とその lepA 及び plcH 破壊株の増殖 A. 腹腔洗浄液中の菌数, B. 全血中の菌数, 全ての組合せに扔いて菌数の差は $\mathrm{P}<0.01$ で有意 (Kida et al., (2011) Infect. Immun. 79, 211219. American Society for Microbiology より転載許諾)。 
液を回収し，菌数を計測した（図 10）。その結果，各菌株 の菌数は野生型 $\mathrm{KU} 2$ 株 (平均 $\log _{10} \mathrm{CFU} / \mathrm{ml}$ 土標準偏差 : 腹 腔洗浄液 $7.18 \pm 0.22$, 全血 $5.85 \pm 0.36)>p l c H$ 破壊株（腹腔 洗浄液 $6.19 \pm 0.33$, 全血 $4.18 \pm 0.31)>l e p A$ 破壊株（腹腔洗 浄液 $4.79 \pm 0.25$, 全血 $2.81 \pm 0.28$ ) >二重破壊株（腹腔洗浄

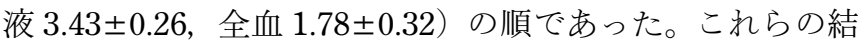
果は，それぞれの菌株の毒力の強さと高い関連性があるこ とを示していた。以上の結果から LepA と $\mathrm{PlcH}$ の協調作用 は, 限定的な栄養源存在下に扔沙膿菌の增殖に関与し, 生体内での緑膿菌の毒力と増殖に寄与することが明らかに なった (21)。

\section{おわりに}

本研究では, 緑膿菌の培養上清から精製された新規のプ ロテアーゼ LepA が，V 型分泌装置の TPS に上る分泌蛋白 質に特徵的な TPS モチーフを有し，PAR-1, - 2, -4 を介して NF-kB を活性化することを見出した (20)。また, LepA が生 体内での緑膿菌の毒力と増殖に寄与することを明らかにし た (21)。しかし，病原性因子としての LepA の機能は，十 分飞解析されていない。例えば, LepA の RGD 細胞接着モ チーフや赤血球凝集活性ドメインが，緑膿菌の病原性にど のような役割を担うのかは不明である。一方，著者らは， 緑膿菌 AT 蛋白質の一つである EprS が，PAR-1, -2, -4 を活 性化するセリンプロテアーゼであることを近年報告したが (22), 生体内に拈ける $\mathrm{EprS}$ の役割は明らかではない。前述 のように, 緑膿菌には PA0041（3,535 アミノ酸, 約 362$\mathrm{kDa}), \operatorname{PA} 0690$ (4,180 アミノ酸, 約 430-kDa), PA2462 (5,627 アミノ酸, 約 $573-\mathrm{kDa}), \mathrm{PA} 2542(1,221$ アミノ酸, 約 130$\mathrm{kDa}$ )といった大きな分子量の機能未知 TpsA 蛋白質の存在 が示唆されている。今後, 緑膿菌の病原性に扣ける $\mathrm{V}$ 型分 泌プロテアーゼ LepA と EprSが果たす役割について更なる 解析を進めると共に, 緑膿菌の機能未知 TpsA 蛋白質の意 義についても検討したい。

\section{謝辞}

本研究を遂行するにあたり，多大なる御指導と御助言を 賜りました桑野剛一先生 (久留米大学教授) 飞深く感謝申 し上げます。さらに，細菌学研究の機会を与えて下さいま した荒井澄夫先生（久留米大学名誉教授）に厚く御礼申し 上げます。また，黒屋奨学賞への推薦を賜りました上西秀 則先生（福岡歯科大学教授）に心より御礼申し上げます。 最後に，多大な御助言と御協力を頂きました共同研究の先 生方，教室員の皆様に深謝致します。

\section{文献}

1) Aristoteli, L.P., Willcox, M.D. (2003): Mucin degradation mechanisms by distinct Pseudomonas aeruginosa isolates in vitro. Infect. Immun. 71, 5565-5575.

2) Benz, I., Schmidt, M.A. (2011): Structures and functions of autotransporter proteins in microbial pathogens. Int. J. Med. Microbiol. 301, 461-468.
3) Bleves, S., Viarre, V., Salacha, R., Michel, G.P., Filloux, A., Voulhoux, R. (2010): Protein secretion systems in Pseudomonas aeruginosa: A wealth of pathogenic weapons. Int. J. Med. Microbiol. 300, 534-543.

4) Borlee, B.R., Goldman, A.D., Murakami, K., Samudrala, R., Wozniak, D.J., Parsek, M.R. (2010): Pseudomonas aeruginosa uses a cyclic-di-GMP-regulated adhesin to reinforce the biofilm extracellular matrix. Mol. Microbiol. 75, 827-842.

5) Caballero, A.R., Moreau, J.M., Engel, L.S., Marquart, M.E., Hill, J.M., O'Callaghan, R.J. (2001): Pseudomonas aeruginosa protease IV enzyme assays and comparison to other Pseudomonas proteases. Anal. Biochem. 290, 330-337.

6) Chung, W.O., Hansen, S.R., Rao, D., Dale, B.A. (2004): Proteaseactivated receptor signaling increases epithelial antimicrobial peptide expression. J. Immunol. 173, 5165-5170.

7) Dulon, S., Leduc, D., Cottrell, G.S., D’Alayer, J., Hansen, K.K., Bunnett, N.W., Hollenberg, M.D., Pidard, D., Chignard, M. (2005): Pseudomonas aeruginosa elastase disables proteinaseactivated receptor 2 in respiratory epithelial cells. Am. J. Respir. Cell Mol. Biol. 32, 411-419.

8) Economou, A., Christie, P.J., Fernandez, R.C., Palmer, T., Plano, G.V., Pugsley, A.P. (2006): Secretion by numbers: Protein traffic in prokaryotes. Mol. Microbiol. 62, 308-319.

9) Filloux, A. (2011): Protein secretion systems in Pseudomonas aeruginosa: An essay on diversity, evolution, and function. Front. Microbiol. 2, 155.

10) Fujita, K., Akino, T., Yoshioka, H. (1988): Characteristics of heatstable extracellular hemolysin from Pseudomonas aeruginosa. Infect. Immun. 56, 1385-1387.

11) Goodman, A.L., Lory, S. (2004): Analysis of regulatory networks in Pseudomonas aeruginosa by genomewide transcriptional profiling. Curr. Opin. Microbiol. 7, 39-44.

12) Hansen, K.K., Sherman, P.M., Cellars, L., Andrade-Gordon, P., Pan, Z., Baruch, A., Wallace, J.L., Hollenberg, M.D., Vergnolle, N. (2005): A major role for proteolytic activity and proteinaseactivated receptor- 2 in the pathogenesis of infectious colitis. Proc. Natl. Acad. Sci. USA 102, 8363-8368.

13) Harrington, S.M., Sheikh, J., Henderson, I.R., Ruiz-Perez, F., Cohen, P.S., Nataro, J.P. (2009): The Pic protease of enteroaggregative Escherichia coli promotes intestinal colonization and growth in the presence of mucin. Infect. Immun. 77, 2465-2473.

14) Henderson, I.R., Navarro-Garcia, F., Desvaux, M., Fernandez, R.C., Ala'Aldeen, D. (2004): Type V protein secretion pathway: the autotransporter story. Microbiol. Mol. Biol. Rev. 68, 692744.

15) Hollenberg, M.D., Compton, S.J. (2002): International Union of Pharmacology. XXVIII. Proteinase-activated receptors. Pharmacol. Rev. 54, 203-217.

16) Holzhausen, M., Spolidorio, L.C., Ellen, R.P., Jobin, M.C., Steinhoff, M., Andrade-Gordon, P., Vergnolle, N. (2006): Protease-activated receptor-2 activation: a major role in the pathogenesis of Porphyromonas gingivalis infection. Am. J. Pathol. 168, 1189-1199.

17) Kanke, T., Macfarlane, S.R., Seatter, M.J., Davenport, E., Paul, A., McKenzie, R.C., Plevin, R. (2001): Proteinase-activated receptor-2-mediated activation of stress-activated protein kinases and inhibitory kappa B kinases in NCTC 2544 keratinocytes. J. Biol. Chem. 276, 31657-31666

18) Kharazmi, A. (1991): Mechanisms involved in the evasion of the host defence by Pseudomonas aeruginosa. Immunol. Lett. 30, 201-205.

19) Kida, Y., Inoue, H., Shimizu, T., Kuwano, K. (2007): Serratia marcescens serralysin induces inflammatory responses through 
protease-activated receptor 2. Infect. Immun. 75, 164-174.

20) Kida, Y., Higashimoto, Y., Inoue, H., Shimizu, T., Kuwano, K. (2008): A novel secreted protease from Pseudomonas aeruginosa activates NF-kappaB through protease-activated receptors. Cell. Microbiol. 10, 1491-1504.

21) Kida, Y., Shimizu, T., Kuwano, K. (2011): Cooperation between LepA and PlcH contributes to the in vivo virulence and growth of Pseudomonas aeruginosa in mice. Infect. Immun. 79, 211-219.

22) Kida, Y., Taira, J., Yamamoto, T., Higashimoto, Y., Kuwano, K. (2013): EprS, an autotransporter protein of Pseudomonas aeruginosa, possessing serine protease activity induces inflammatory responses through protease-activated receptors. Cell. Microbiol. 15, 1168-1181.

23) Leo, J.C., Grin, I., Linke, D. (2012): Type V secretion: mechanism(s) of autotransport through the bacterial outer membrane. Philos. Trans. R. Soc. B 367, 1088-1101.

24) Lourbakos, A., Potempa, J., Travis, J., D’Andrea, M.R., AndradeGordon, P., Santulli, R., Mackie, E.J., Pike, R.N. (2001): Arginine-specific protease from Porphyromonas gingivalis activates protease-activated receptors on human oral epithelial cells and induces interleukin-6 secretion. Infect. Immun. 69, 5121-5130.

25) Luckett, J.C., Darch, O., Watters, C., Abuoun, M., Wright, V., Paredes-Osses, E., Ward, J., Goto, H., Heeb, S., Pommier, S., Rumbaugh, K.P., Cámara, M., Hardie, K.R. (2012): A novel virulence strategy for Pseudomonas aeruginosa mediated by an autotransporter with arginine-specific aminopeptidase activity. PLoS Pathog. 8, e1002854.

26) Ma, Q., Zhai, Y., Schneider, J.C., Ramseier, T.M., Saier, M.H., Jr. (2003): Protein secretion systems of Pseudomonas aeruginosa and $P$. fluorescens. Biochim. Biophys. Acta 1611, 223-233.

27) Macfarlane, S.R., Seatter, M.J., Kanke, T., Hunter, G.D., Plevin, R. (2001): Proteinase-activated receptors. Pharmacol. Rev. 53, 245-282.

28) Maeda, H. (1996): Role of microbial proteases in pathogenesis. Microbiol. Immunol. 40, 685-699.

29) Mazar, J., Cotter, P.A. (2007): New insight into the molecular mechanisms of two-partner secretion. Trends Microbiol. 15, 508-515.

30) McLaughlin, J.N., Patterson, M.M., Malik, A.B. (2007): Protease-activated receptor-3 (PAR3) regulates PAR1 signaling by receptor dimerization. Proc. Natl. Acad. Sci. USA 104, 56625667.

31) Mietzner, T.A., Morse, S.A. (1994): The role of iron-binding proteins in the survival of pathogenic bacteria. Annu. Rev. Nutr. 14, 471-493.

32) Nakanishi-Matsui, M., Zheng, Y.W., Sulciner, D.J., Weiss, E.J., Ludeman, M.J., Coughlin, S.R. (2000): PAR3 is a cofactor for PAR4 activation by thrombin. Nature 404, 609-613.
33) O'Callaghan, R.J., Engel, L.S., Hobden, J.A., Callegan, M.C., Green, L.C., Hill, J.M. (1996): Pseudomonas keratitis. The role of an uncharacterized exoprotein, protease IV, in corneal virulence. Invest. Ophthalmol. Vis. Sci. 37, 534-543.

34) Ossovskaya, V.S., Bunnett, N.W. (2004): Protease-activated receptors: contribution to physiology and disease. Physiol. Rev. 84, 579-621.

35) Ostroff, R.M., Wretlind, B., Vasil, M.L. (1989): Mutations in the hemolytic-phospholipase $\mathrm{C}$ operon result in decreased virulence of Pseudomonas aeruginosa PAO1 grown under phosphatelimiting conditions. Infect. Immun. 57, 1369-1373.

36) Otto, B.R., Verweij-van Vught, A.M., MacLaren, D.M. (1992): Transferrins and heme-compounds as iron sources for pathogenic bacteria. Crit. Rev. Microbiol. 18, 217-233.

37) Potempa, J., Pike, R.N. (2009): Corruption of innate immunity by bacterial proteases. J. Innate. Immun. 1, 70-87.

38) Preston, M.J., Seed, P.C., Toder, D.S., Iglewski, B.H., Ohman, D.E., Gustin, J.K., Goldberg, J.B., Pier, G.B. (1997): Contribution of proteases and LasR to the virulence of Pseudomonas aeruginosa during corneal infections. Infect. Immun. 65, 30863090.

39) Ramachandran, R., Hollenberg, M.D. (2008): Proteinases and signalling: pathophysiological and therapeutic implications via PARs and more. Br. J. Pharmacol. 153 Suppl 1, S263-282.

40) Ramachandran, R., Noorbakhsh, F., Defea, K., Hollenberg, M.D. (2012): Targeting proteinase-activated receptors: therapeutic potential and challenges. Nat. Rev. Drug Discov. 11, 69-86.

41) Rothmeier, A.S., Ruf, W. (2012): Protease-activated receptor 2 signaling in inflammation. Semin. Immunopathol. 34, 133-149.

42) Shpacovitch, V., Feld, M., Bunnett, N.W., Steinhoff, M. (2007): Protease-activated receptors: novel PARtners in innate immunity. Trends Immunol. 28, 541-550.

43) Stover, C.K., Pham, X.Q., Erwin, A.L., Mizoguchi, S.D., Warrener, P., Hickey, M.J., et al. (2000): Complete genome sequence of Pseudomonas aeruginosa PAO1, an opportunistic pathogen. Nature 406, 959-964.

44) Suter, S. (1994): The role of bacterial proteases in the pathogenesis of cystic fibrosis. Am. J. Respir. Crit. Care Med. 150, S118-122.

45) Wee, J.L., Chionh, Y.T., Ng, G.Z., Harbour, S.N., Allison, C., Pagel, C.N., Mackie, E.J., Mitchell, H.M., Ferrero, R.L., Sutton, P. (2010): Protease-activated receptor-1 down-regulates the murine inflammatory and humoral response to Helicobacter pylori. Gastroenterology 138, 573-582.

46) Wilhelm, S., Gdynia, A., Tielen, P., Rosenau, F., Jaeger, K.E. (2007): The autotransporter esterase EstA of Pseudomonas aeruginosa is required for rhamnolipid production, cell motility, and biofilm formation. J. Bacteriol. 189, 6695-6703. 


\title{
Roles of Pseudomonas aeruginosa-derived proteases as a virulence factor
}

\author{
Yutaka KIDA $^{1}$ \\ ${ }^{1}$ Division of Microbiology, Department of Infectious Medicine, Kurume University School of Medicine, \\ 67 Asahi-machi, Kurume, Fukuoka 830-0011
}

The major virulence factors produced by Pseudomonas aeruginosa include secreted proteases that damage host tissues. Of the proteases analyzed, alkaline protease (AprA) and elastase B (LasB) have been characterized extensively. Although $P$. aeruginosa protein database predicts the presence of several other potential proteases, little has been known about the proteases involving in the pathogenicity of this organism. In this study, we found that $P$. aeruginosa produces a novel large extracellular protease (LepA) distinct from known proteases such as AprA and LasB. Sequence analysis of LepA showed a molecular future of the proteins transported by the two-partner secretion pathway. We demonstrated that LepA can activate NF- $\mathrm{NB}$-driven promoter through protease-activated receptor-1, -2 or -4 . On the other hand, one of the functions of proteases is to hydrolyze proteins and peptides for nutrient acquisition either by degrading host enzymes or even by causing tissue damage to further the survival of the bacterium. Therefore, to investigate the role of LepA in in vivo virulence and growth of $P$. aeruginosa, we compared the virulence and growth of a wild-type strain and its mutant using a mouse model of acute systemic infection by $P$. aeruginosa. Our results suggest that LepA contributes to the in vivo virulence and growth of $P$. aeruginosa. 